

\section{DISCLAIMER}

This document was prepared as an account of work sponsored by an agency of the United States Government. Neither the United States Government nor the University of California nor any of their employees, makes any warranty, express or implied, or assumes any legal liability or responsibility for the accuracy, completeness, or usefulness of any information, apparatus, product, or process disclosed, or represents that its use would not infringe privately owned rights. Reference herein to any specific commercial product, process, or service by trade name, trademark, manufacturer, or otherwise, does not necessarily constitute or imply its endorsement, recommendation, or favoring by the United States Government or the University of California. The views and opinions of authors expressed herein do not necessarily state or reflect those of the United States Government or the University of California, and shall not be used for advertising or product endorsement purposes.

This report has been reproduced directly from the best available copy.

Available to DOE and DOE contractors from the Office of Scientific and Technical Information P.O. Box 62, Oak Ridge, TN 37831

Prices available from (615) 576-8401, FTS 626-8401

Available to the public from the

National Technical Information Service

U.S. Department of Commerce 5285 Port Royal Rd., Springfield, VA 22161 


\section{DISCLAIMER}

Portions of this document may be illegible in electronic image products. Images are produced from the best available original document. 


\title{
Coupled Chemistry/Climate Issues
}

\author{
Douglas A. Rotman \\ Global Climate Research Division \\ Lawrence Livermore National Laboratory \\ Livermore, CA 94550 \\ Donald J. Wuebbles \\ Department Chairman, Atmospheric Sciences \\ University of Illinois \\ Urbana, Illinois 61801
}

Driven by both natural and anthropogenic causes, the distributions of trace chemical species in the atmosphere has altered the natural state of the chemical distribution and, we believe, the climate system. A clear example of this change and its effect on climate is through tropospheric ozone. Evidence shows that over the last decade tropospheric ozone has increased (Oltmans and Komhyr, 1986; Logan, 1985), probably caused by increasing concentrations and emissions of $\mathrm{CH}_{4}, \mathrm{CO}, \mathrm{NO}_{\mathrm{x}}$, and NMHCs (nonmethane hydrocarbons). Tropospheric ozone is an important greenhouse gas that also impacts human health, agricultural crops and ecosystems. Tropospheric ozone is photochemically produced when nitrogen oxides react in the presence of carbon monoxide, methane, non-methane hydrocarbons and sunlight. The chemistry of ozone and $\mathrm{NO}_{\mathrm{x}}$ is also closely associated with the hydroxyl radical $(\mathrm{OH})$, which governs the atmospheric lifetime of a number of species, including $\mathrm{CH}_{4}$ and chlorofluorcarbons (CFCs), which are major greenhouse gases and which affect the chemical balance of the stratosphere. Increases in the concentrations of $\mathrm{CO}$ and $\mathrm{CH}_{4}$ can lead to decreased concentrations of $\mathrm{OH}$ and a positive feedback on the atmospheric lifetimes of $\mathrm{CO}$ and methane (Wuebbles and Tamaresis, 1992). The same would occur for other greenhouse gases and for some of the important reactions which form aerosols in the troposphere. This would further enhance the concentrations of the gases and accelerate the radiative effects from these greenhouse species, strongly affecting climate and the accurate prediction of climate. It is believed that warmer climates will also increase the amount of water in the atmosphere, thereby providing another chemistry feedback on $\mathrm{OH}$.

Historical analysis of atmospheric chemistry and climate has, until the very recent past (Taylor and Penner, 1994), always studied those aspects separately, i.e., separate atmospheric chemistry and climate models. The increasing power of stand along supercomputers and the wider availability of the massively parallel computers, which we believe will provide the real ability for coupled model simulations, now provide the computational capabilities for higher levels of modeling. We believe that the scientific

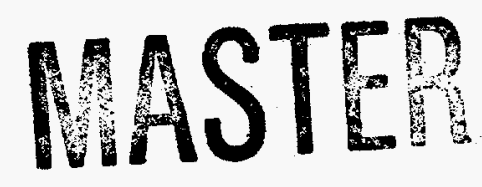


needs and computational abilities now exist to warrant the discussion of coupling the chemistry and climate models. Within this context, several key questions must be analyzed,

- What are the most important processes that couple chemistry and climate?

- Given the need to couple chemistry and climate, how frequently must it be coupled?

- How do these processes that couple chemistry with climate affect climate variability?

- How do variations in the meteorological fields alter the chemistry/climate coupling and affect climate variability and prediction?

These questions can only be fully answered through the development of interactively coupled chemistry/climate models. For such modeling, important variables are required to be exchanged between the two models. The climate model would provide the transport wind fields to advect the trace species. In addition, the GCM would provide the humidity and liquid water fields that are important in the calculation of some tropospheric chemistry and cloud phenomena. These water profiles and the GCM provided temperature fields could be combined to calculate moist convection, or alternatively, the calculated mass flux from convection in the GCM can be exchanged to the chemistry model. The convection of trace species from the PBL or lower troposphere to the free and upper troposphere, and possibly into the stratosphere, provides a key linkage of the chemistry and climate models. Ground emitted trace species become mixed into the troposphere through the PBL. The GCM would also provide the diurnal variation in the PBL height while the chemistry model would deal with the wet and dry deposition of the chemical species.

The reverse flow of information, that is from the chemistry model to the climate model, is also important. The chemistry model will provide the global distributions of the radiatively important species, such as $\mathrm{O}_{3}, \mathrm{~N}_{2} \mathrm{O}, \mathrm{CH}_{4}$ and $\mathrm{CFCs}$. These species will provide key information for the calculation of the heating rate fields and circulation patterns of the GCM. Aerosols provide the dual role of being important to the radiation balance of the atmosphere as well as a site for heterogeneous chemistry and hence play an complex and important role in the coupling of chemistry and climate models.

These interactions provide not only interesting and exciting scientific problems, but computational problems as well. Climate modeling depends on a delicate balance among the climate processes and hence some level of so called "tuning" within the 
climate model. It remains to be seen whether any interaction of the chemistry and climate is strong enough to force a "re-tuning" of the climate model, but items like volcanic eruptions and the long term trends in stratospheric and tropospheric ozone could provide large enough alterations in the climate system to require this re-tuning. The vertical resolution of the troposphere, especially with regard to water vapor, is very important. The addition of chemistry may further this importance and require even higher accuracy. The modeling of atmospheric chemistry is complicated for many reasons, key among them is the stiffness of the chemistry. Hence, it is likely that portions of the atmospheric could accept large chemistry model time steps while others may require very short time steps. An important question then becomes, which model determines the overall time step? Another way of asking this question is, how often do you have to couple the chemistry and climate model. The time step for the chemistry must be large enough to enable the computational expensive calculations to actually take place, but short enough to bring the important time varying processes such as changes in the circulation patterns, and temperature patterns for transport and chemical rate coefficient calculations; as well as the diurnal variation of the PBL.

There is now the scientific need and computational abilities for the coupling of atmospheric chemistry and climate. Key questions remain as to the ability of these models to be interactively coupled. Key coupling processes and variables are large, but, at least initially, identified. We believe efforts should be put forth to advance the coupled models and advance the scientific understand of the atmospheric chemistry and climate system. To this end, we have established a list of recommendations for future modeling efforts.

1. Massively parallel computers will be the architecture of choice for near term future coupled chemistry climate models. These are the only computers capable of the computational throughput needed for coupled models. Models will be required to make use of these computers and those computers must be made available to those doing this research.

2. Separate linking modules will be required to provide the capability of exchanging model variables. These linking modules will provide model resolution/grid interpolation and any needed variable unit changes (i.e., meters to centimeters).

3. Chemistry models and climate models will need to be written in standard languages (Fortran, C, etc., etc.) and in a modular fashion. This is required for portability 
among the fast changing massively parallel computers and to allow easy and quick exchange, comparison and addition of sub-models within the chemistry and climate models.

4. Both the chemistry model and climate model must include, at least, the troposphere and stratosphere, along with a full set of data from natural and anthropogenic land based emissions.

5. Ideally, a computational framework should be used that would provide the long term future capabilities of linking the coupled chemistry/climate models with an ocean GCM and ecosystem models.

6. Initial studies must establish the time scale at which chemistry and climate models exchange data.

This work was performed under the auspices of the U.S. Department of Energy by Lawrence Livermore National Laboratory under contract no. W-7405-Eng-48.

\section{Bibliography}

Logan, J.A., 1985: Tropospheric ozone: Seasonal behavior, trends, and anthropogenic influence, J. Geophys. Res.,, 90, 10463-10482.

Oltmans, S. J., and W. D. Komhyr, 1986: Surface ozone distributions and variations from 1973-1984 measurements at the NOAA Geophysical monitoring for climatic change baseline observatories, J. Geophys. Res., 91, 5229-5236.

Wuebbles, D.J., and J. Tamaresis, 1992: The role of methane in the global environment, Atmospheric Methane, M.A.K. Khalil, editor, Springer-Verlag Publishers; also Lawrence Livermore National Laboratory report UCRL-JC-109880.

Taylor. K.E. and J.E. Penner, 1994: Response of the climate system to atmospheric aerosols and greenhouse gases, Nature., 369, 734-737. 